\title{
ANALISIS FAKTOR - FAKTOR YANG MEMPENGARUHI ALIH FUNGSI LAHAN PERSAWAHAN MENJADI LAHAN PERKEBUNAN DI KECAMATAN SUNGAI BATANG KABUPATEN INDRAGIRI HILIR
}

\author{
Zainal Azhar \\ Program Studi Agribisnis Fakultas Pertanian UNISI \\ Email: zainalazhar7@gmail.com
}

\begin{abstract}
ABSTRAK
Alih fungsi lahan atau lazimnya disebut sebagai konversi lahan adalah perubahan fungsi sebagian atau seluruh kawasan lahan dari fungsinya semula menjadi fungsi lain yang menjadi dampak negatif terhadap lingkungan dan potensi lahan itu sendiri. Tujuan dalam penelitian ini adalah untuk mengetahui apakah faktor ekonomi, sosial, kondisi lahan dan pemerintah mempengaruhi keputusan petani mengkonversi lahan persawahannya menjadi lahan perkebunan dan mengetahui besar pengaruh variabel ekonomi (X1), sosial (X2), kondisi lahan (X3), dan pemerintah (X4) terhadap keputusan petani mengkonversi lahan persawahannya menjadi lahan perkebunan di Kecamatan Sungai Batang. Metode analisis data yang digunakan dalam penelitian ini adalah analisis regresi linier berganda dengan jumlah sampel 70 orang. Hasil penelitian ini menunjukkan tiga variabel berpengaruh signifikan terhadap keputusan petani mengkonversi lahan yaitu faktor ekonomi, sosial dan kondisi lahan. Koefisien regresi variabel ekonomi adalah 0,809 $(\alpha=1 \%)$, sosial $-0,177(\alpha=5 \%)$, dan kondisi lahan 0,170 $(\alpha=5 \%)$ sedangkan untuk variabel peraturan pemerintah/uu tidak berpengaruh signifikan.
\end{abstract}

Kata-kata kunci : alih fungsi lahan, sawah, perkebunan

\section{PENDAHULUAN}

Lahan merupakan sumber daya bagi petani dalam melakukan kegiatan pertanian. Lahan yang luas akan semakin memperbesar harapan petani untuk dapat hidup layak. Seiring dengan meningkatnya jumlah penduduk, keberadaan lahan terutama lahan pertanian menjadi semakin terancam dikarenakan kebutuhan akan lahan yang lebih banyak. Sementara jumlah tanah yang tersedia tidak bertambah. Fenomena inilah yang kemudian memacu terjadinya konversi lahan pertanian. Menurut Utomo (1992), alih fungsi lahan atau lazimnya disebut sebagai konversi lahan didefinisikan sebagai perubahan fungsi sebagian atau seluruh kawasan lahan dari fungsinya semula (seperti yang direncanakan) menjadi fungsi lain yang membawa dampak negatif (masalah) terhadap lingkungan dan potensi lahan itu sendiri.

Harga jual produk-produk pertanian merupakan faktor petani mengkonversi lahanya. Selain membutuhkan modal yang lumayan, para petani juga harus siap menerima resiko lain, yakni hasil panen yang tidak baik atau bahkan gagal panen. Dimana harga jual produk pertaniannya menjadi sangat rendah atau malah tidak laku di pasaran. Jika hal ini terjadi maka petani akan 
menderita kerugian yang tidak sedikit pula. Tantangan lain ialah adanya penurunan harga hasil pertaniannya karena faktor-faktor tertentu (Irawan 2002).

Kurangnya minat generasi muda untuk mengelola lahan pertanian juga merupakan faktor terjadinya alih fungsi lahan. Anggapan masyarakat, khususnya para generasi muda mengenai sektor pertanian masih belum sepopuler bidang-bidang usaha yang lain. Para pemuda misalnya, ketika ditanya mengenai cita-cita mereka, maka hampir bisa dipastikan akan menyebutkan berbagai profesi lain selain menjadi petani. Meski tidak sedikit juga masyarakat yang telah menjadi petani sukses, namun profesi petani saat ini memang masih sering dianggap sebagai profesi yang berada pada kelas menengah ke bawah, sehingga cenderung dihindari oleh para generasi muda. Dan sebagai akibatnya, para orang tua yang mempunyai sawah atau lahan pertanian akan menjual lahannya kepada orang lain. Sedangkan bagi mereka yang mewariskan kepada anaknya yang tidak berminat mengelola sawah, maka besar kemungkinan lahan tersebut akan mengalami alih fungsi (Irawan 2002).

Alih fungsi lahan juga dapat terjadi oleh karena kurangnya insentif pada usahatani lahan sawah yang diduga akan menyebabkan terjadi alih fungsi lahan ke tanaman pertanian lainnya. Permasalahan tersebut diperkirakan akan mengancam kesinambungan produksi beras nasional.

Selama periode 2014 luas panen tanaman padi di Provinsi Riau mengalami penurunan sebesar 10,55 persen yaitu dari 118.518 hektar menjadi 106.037 hektar.Kabupaten
Indragiri Hilir adalah salah satu kabupaten yang mengalami menurunan luas lahan sawah, tahun 2006 sampai 2015 luas lahan sawah Kabupaten Indragiri Hilir mengalami penurunan sebesar 25.949 haktar (BPS Provinsi Riau).

Salah satu daerah yang mengalami alih fungsi lahan di Kabupaten Indragiri Hilir adalah Kecamatan Sungai Batang, Usahausaha yang dilakukan pemerintah untuk melindungi lahan pertanian tanaman pangan belum sepenuhnya mampu mengendalikan alih fungsi lahan. Oleh karena itu diperlukan kajian untuk mengetahui faktor-faktor apa yang mempengaruhi petani melakukan alih fungsi lahan tersebut, sehingga diperoleh informasi yang komprehensif yang dapat dijadikan sebagai dasar dalam pengambilan kebijakan ke depan. Berdasarkan latar belakang tersebut maka tujuan penelitian ini adallah untuk mengetahui faktor - faktor yang mempengaruhi terjadinya alih fungsi lahan persawahan menjadi lahan perkebunan dan untuk mengatahui berapa besar pengaruh faktor-faktor tersebut terhadap alih fungsi lahan persawahan menjadi lahan perkebunan di Kecamatan Sungai Batang.

\section{TINJAUAN PUSTAKA}

\subsection{Lahan Pertanian}

Lahan mempunyai arti penting bagi para stakeholder yang memanfaatkannya. Fungsi lahan bagi masyarakat sebagai tempat tinggal dan sumber mata pencaharian. Bagi petani, lahan merupakan sumber memproduksi makanan dan keberlangsungan hidup. Bagi pihak swasta, lahan adalah aset untuk mengakumulasikan modal. Bagi pemerintah, lahan merupakan 
kedaulatan suatu negara dan untuk kesejahteraan rakyatnya. Adanya banyak kepentingan yang saling terkait dalam penggunaan lahan, hal ini mengakibatkan terjadinya tumpang tindih kepentingan antar aktor yaitu petani, pihak swasta, dan pemerinntah dalam memanfaatkan lahan (FAO dalam Arsyad, 1989).

Lahan pertanian merupakan lahan yang diperuntukan untuk kegiatan pertanian. Sumberdaya lahan pertanian memiliki banyak manfaat bagi manusia. Menurut Sumaryanto dan Tahlim (2005) menyebutkan bahwa manfaat lahan pertanian dapat dibagi menjadi dua kategori. Pertama, use values atau nilai penggunaan dapat pula disebut sebagai personal use values. Manfaat ini dihasilkan dari hasil eksploitasi atau kegiatan usahatani yang dilakukan pada sumber daya lahan pertanian. Kedua, non use values dapat pula disebut sebagai intrinsic values atau manfaat bawaan. Berbagai manfaat yang tercipta dengan sendirinya walaupun bukan merupakan tujuan dari kegiatan eksploitasi dari pemilik lahan pertanian termasuk dalam kategori ini.

\subsection{Alih fungsi lahan}

Alih fungsi lahan atau lazimnya disebut sebagai konversi lahan adalah perubahan fungsi sebagian atau seluruh kawasan lahan dari fungsinya semula (seperti yang direncanakan) menjadi fungsi lain yang menjadi dampak negatif (masalah) terhadap lingkungan dan potensi lahan itu sendiri. Alih fungsi lahan dalam artian perubahan/penyesuaian peruntukan penggunaan, disebabkan oleh faktorfaktor yang secara garis besar meliputi keperluan untuk memenuhi kebutuhan penduduk yang makin bertambah jumlahnya dan meningkatnya tuntutan akan mutu kehidupan yang lebih baik (Utomo dkk ,1992).

Beberapa penyebab tingginya alih fungsi lahan diantaranya rendahnya tingkat keuntungan bertani padi sawah, tidak dipatuhinya peraturan tata ruang (lemahnya penegakan hukum tentang tata ruang), keinginan mendapatkan keuntungan jangka pendek dari pengalihfungsian lahan sawah, dan rendahnya koordinasi antara lembaga dan departemen terkait dengan perencanaan penggunaan lahan (Nasoetion dan Winoto, 1996).

Rahmanto, dkk, (2008), menyatakan karakteristik rumahtangga memiliki hubungan kuat terhadap keragaman persepsi multi fungsi lahan sawah di antaranya mencakup peubah-peubah berikut: (1) usia responden; (2) tingkat pendidikan; (3) jumlah anggota keluarga tertanggung; (4) luas garapan sawah; (5) proporsi pendapatan rumahtangga dari lahan sawah. Peubah-peubah tersebut diasumsikan memiliki keterkaitan yang nyata terhadap kemampuan berfikir, tingkat pengetahuan serta wawasan petani terhadap multifungsi lahan, dan kepeduliannya terhadap kelestarian lahan sawah.

\subsection{Faktor-Faktor Mempengaruhi Alih fungsi Lahan}

Ditinjau menurut prosesnya, konversi lahan sawah dapat terjadi: secara gradual dan secara seketika (instant). Alih fungsi secara gradual lazimnya disebabkan fungsi sawah tidak optimal. Umumnya hal seperti ini terjadi akibat degradasi mutu irigasi atau usaha tani padi di lokasi 
tersebut tidak dapat berkembang karena kurang menguntungkan. Alih fungsi secara instant pada umumnya berlangsung di wilayah sekitar urban, yakni berubah menjadi lokasi pemukiman atau kawasan industry Sumaryanto et al (1995).

Proses terjadinya alih fungsi lahan pertanian ke penggunaan non pertanian disebabkan oleh beberapa faktor. Kustiwan (1997) menyatakan bahwa setidaknya ada tiga faktor penting yang menyebabkan terjadinya alih fungsi lahan sawah yaitu:

1. Faktor Eksternal. Merupakan faktor yang disebabkan oleh adanya dinamika pertumbuhan perkotaan (fisik maupun spasial), demografi maupun ekonomi.

2. Faktor Internal. Faktor ini lebih melihat sisi yang disebabkan oleh kondisi sosial-ekonomi rumah tangga pertanian pengguna lahan.

3. Faktor Kebijakan. Yaitu aspek regulasi yang dikeluarkan oleh pemerintah pusat maupun daerah yang berkaitan dengan perubahan fungsi lahan pertanian.

Pasandaran

menjelaskan paling tidak ada tiga faktor, baik sendiri-sendiri maupun bersama-sama yang merupakan determinan konversi lahan sawah, yaitu: (1). Kelangkaan sumberdaya lahan dan air, (2). Dinamika pembangunan, (3). Peningkatan jumlah penduduk.

Pakpahan, et.al (1993) dalam Munir (2008) membagi faktor yang mempengaruhi konversi dalam kaitannya dengan petani, yakni faktor tidak langsung dan faktor langsung. Faktor tidak langsung antara lain perubahan struktur ekonomi, petumbuhan penduduk, arus urbanisasi dan konsistensi implementasi rencana tata ruang.
Sedangkan faktor langsung dipengaruhi oleh pertumbuhan pembangunan sarana transportasi, pertumbuhan kebutuhan lahan untuk industri, pertumbuhan sarana pemukiman dan sebaran lahan sawah.

Adapun faktor-faktor yang mempengaruhi konversi lahan sawah di tingkat petani, sebagaimana dikemukakan oleh Rusastra (1994) dalam Munir (2008) adalah sebagai pilihan alokasi sumber daya melalui transaksi yang dipengaruhi oleh kondisi sosial ekonomi petani seperti tingkat pendidikan, pendapatan dan kemampuan ekonomi secara keseluruhan serta pajak tanah, harga tanah dan lokasi tanah. Sehingga diperlukan kontrol agar sesuai dengan rencana tata ruang.

\section{METODE PENELITIAN \\ 3.1.Tempat dan Waktu Penelitian}

Penelitian di lakukan di Kecamatan Sungai Batang Kabupaten Indragiri Hilir Provinsi Riau. Pemilihan lokasi dilakukan secara sengaja dikarenakan Kecamatan Sungai Batang adalah salah satu sentra produksi padi di Kabupaten Indragiri Hilir yang saat ini mengalami alih fungsi lahan sawah menjadi perkebunan (Dinas Tanaman Pangan, Hortikultura, dan Peternakan Kabupaten Indagiri Hilir). Penelitian ini dilaksanakan pada bulan Agustus sampai dengan Oktober 2016.

\subsection{Jenis dan Sumber Data}

Dalam penelitian ini data yang digunakan adalah data primer dan data sekunder. Data primer diperoleh secara langsung dari para responden dengan mengunakan kuesioner. Data sekunder diperoleh melalui Badan 
Pusat Statistik (BPS), Dinas Tanaman Pangan Hortikultura dan Peternakan, Dinas Perkebunan Kabupaten Indragiri Hilir serta berbagai literatur lain yang berkaitan dengan penelitian ini. Salah satu data sekunder yang di ambil adalah luas lahan sawah dan perkebunan di Kecamatan Sungai Batang.

\subsection{Populasi dan Sampel}

\section{Pengambilan} sampel

dilakukan dalam dua tahap. Pertama adalah menentukan sampel desa yang dilakukan secara purpossive sampling. Jumlah desa yang dipilih sebanyak 1 kelurahan dan 3 desa, yaitu kelurahan Benteng, Desa Benteng Utara, Desa Benteng Barat dan Desa Mugomulyo. Kedua adalah menentukan petani sampel. Pengambilan petani sampel dilakukan secara purpossive sampling dengan batasan - batasan yang akan menjadi sampel dalam penelitian ini adalah petani pemilik lahan yang mengkonversi lahan sawahnya menjadi lahan perkebunan dengan jumlah sampel 70 petani.

\subsection{Metode Analisis Data}

\subsubsection{Kuantifikasi Data}

Analisis kuantitatif adalah analisis data yang menggunakan data berbentuk angka-angka yang diperoleh sebagai hasil pengukuran atau penjumlahan. Untuk mendapatkan data kuantitatif, digunakan skala likert yang diperoleh dari daftar pertanyaan yang digolongkan kedalam lima tingkatan sebagai berikut:

- Untuk jawaban STS (sangat tidak setuju) diberi nilai ) $=1$

- Untuk jawaban TS (tidak setuju) diberi nilai $=2$

- Untuk jawaban N (netral) diberi nilai $=3$
- Untuk jawaban S (setuju) diberi nilai $=4$

- Untuk jawaban SS (sangat setuju ) diberi nilai $=5$

\subsubsection{Analisis Regresi Linier Berganda}

Analisis data penelitian ini juga dilakukan dengan mengunakan uji Regresi Linier Berganda. Uji ini digunakan untuk mengetahui pengaruh antar faktor ekonomi, faktor sosial, faktor kondisi lahan dan faktor peraturan pemerintah/UU terhadap keputusan petani mengkonversi lahan persawahan. Rumus Uji Regresi Linier Berganda yang digunakan sebagai berikut :

$\mathrm{Y}=\mathrm{a}+\mathrm{b}_{1} \mathrm{x}_{1}+\mathrm{b}_{2} \mathrm{x}_{2}+\mathrm{b}_{3} \mathrm{x}_{3}+\mathrm{b}_{4} \mathrm{x}_{4}$ $+\mathrm{e}$

Dimana :

Y : Keputusan petani

Mengkonversi Lahan

a : Nilai konstantayang akan diperoleh

b1 - b4: Koefisien regresi dari X1$\mathrm{X} 4$

X1 : Faktor Ekonomi

$\mathrm{X} 2$ : Faktor Sosial

X3 : Faktor Kondisi Lahan

X4 : Peraturan Pemerintah

E : Error

Defenisi dari variabel-variabel yang digunakan untuk mengetahui faktor-faktor apa saja yang mempengaruhi petani mengkonversi lahan persawahan menjadi lahan perkebunan dalam penelitian ini antara lain :

1. Keputusan Petani Mengkonversi Lahan persawahan menjadi lahan perkebunan (Y)

Keputusan untuk mengkonversi lahan persawahan menjadi lahan perkebunan merupakan pilihan bagi petani guna meningkatkan pendapatan 
dari tanah yang dimiliki sebagai respon tindakan atas beberapa faktor yang mempengaruhi. Keputusan petani mengkonversi lahan dapat diukur dengan menjumlahkan frekuensi skor yang diperoleh dari hasil kuesioner masing-masing indikator instrumen yaitu persepsi petani terhadap perubahan ekonomi, perubahan taraf sosial, produktivitas lahan, dan dukungan pemerintah saat mengkonversi lahan tersebut.

2. Faktor Ekonomi (X1)

Faktor ekonomi ditentukan dengan menjumlahkan frekuensi skor dari beberapa indikator yang terkait dengan kondisi ekonomi responden seperti 1) tanggungan keluarga, 2) pendapatan sektor pertanian yang tidak mencukupi, 3) Tuntutan kebutuhan hidup yang semakin tinggi dan, 4) modal pertanian yang besar.

3. Faktor Sosial (Berkurangnya nilai nilai budaya masyarakat dalam pengelolaan lahan- lahan pertanian) (X2)

Faktor sosial merupakan pendapat atau pandangan terhadap nilai - nilai budaya yang ada didalam masyarakat (baik masyarakat yang terkait langsung dengan bidang pertanian maupun masyarakat yang tidak terkait langsung dalam bidang pertanian) terhadap lahan-lahan pertanian. Faktor sosial ditentukan dengan menjumlahkan frekuensi skor dari beberapa indikator seperti: 1) tradisi kegotongroyongan yang mulai memudar, 2) hilangnya nilai budaya masyarakat desa dalam pengelolaan lahan pertanian serta, 3) tidak adanya lagi penerus generasi muda yang bekerja di sektor pertanian.
4. Faktor Kondisi Lahan (X3)

Faktor Kondisi Lahan ditentukan dengan menjumlahkan frekuensi skor dari beberapa indikator yang terkaitdengan karakteristik lahan yang dimiliki petani seperti: 1) lokasilahan, 2) luas lahan, 3) produktivitas lahan dan, 4) penghasilan dari lahanyang dimiliki petani atas lahan pertaniannya.

5. Peraturan Pemerintah / UU (X4) Peraturan Pemerintah ditentukan dengan menjumlahkan frekuensi skor dari beberapa indikator yang terkait dengan kebijakan pemerintah dalam pengelolaan lahan-lahan pertanian, diantaranya peraturan / komitmen pemerintah yang masih rendah dalam pengelolaan lahan - lahan pertanian dan pengendalian konversi lahan persawahan menjadi lahan perkebunan yang masih rendah.

\subsubsection{Pengujian model}

Untuk menguji model regresi yang telah diperoleh dilakukan pengujian model sebagai berikut :

\section{a. R-Square}

R-Square atau koefesien determinasi digunakan untuk mengetahui seberapa besar persentase sumbangan variabel bebas terhadap variabel terikat yang dapat dinyatakan dalam persentase. Besarnya persentase pengaruh semua variabel independent terhadap nilai variabel dependent dapat diketahui dari besarnya koefisien determinasi $\left(\mathrm{R}^{2}\right)$ persamaan regresi (Gujarati, 1995).

\section{b. Uji F}

Uji $F$ di gunakan untuk 
mengetahui apakah semua variabel indevendent $\left(\mathrm{X}_{1}\right)$ faktor ekonomi, $\left(\mathrm{X}_{2}\right)$ faktor sosial, $\left(\mathrm{X}_{3}\right)$ faktor kondisi lahan, $\left(\mathrm{X}_{4}\right)$ faktor peraturan pemerintah/uu secara bersama-sama berpengaruh terhadap variabel dependent yaitu keputusan petani mengkonversi lahan sawah ke lahan perkebunan (Y) di Kecamatan Sungai Batang (Gujarati, 2006), dengan kriteria:

- Apabila $F_{\text {hitung }}>F_{\text {tabel }}:$
Signifikan
Apabila $F_{\text {hitung }}<F_{\text {tabel }}$ : Tidak
Signifikan

\section{c. Uji t}

Uji ini digunakan untuk mengetahui apakah masing-masing variabel independen mempunyai pengaruh secara signifikan terhadap variabel dependen. Dengan kata lain, untuk mengetahui apakah masingmasing variabel independen dapat menjelaskan perubahan yang terjadi pada variabel dependen. Uji $t$ digunakan untuk mengetahui apakah variabel, $\left(\mathrm{X}_{1}\right)$ faktor ekonomi, $\left(\mathrm{X}_{2}\right)$ faktor sosial, $\left(\mathrm{X}_{3}\right)$ faktor kondisi lahan, $\left(\mathrm{X}_{4}\right)$ faktor peraturan pemerintah/uu. Berpengaruh nyata terhadapa keputusan petani mengkonversi lahan (Y) sawah ke lahan perkebunan di Kecamatan Sungai Batang, dengan kriteria :

- $\quad$ Apabila $t_{\text {hitung }}>t_{\text {tabel }}$ : Variabel Signifikan

- $\quad$ Apabila $t_{\text {hitung }}<t_{\text {tabel }}$ : Variabel Tidak Signifikan

\subsubsection{Uji Asumsi Klasik}

Model regresi linier berganda dapat disebut sebagai model yang baik jika model tersebut memenuhi beberapa asumsi yang kemudian disebut dengan asumsi klasik. Dalam penelitian ini, akan digunakan deteksi multikolinieritas, deteksi autokorelasi dan deteksi heteroskedastisitas.

\section{a. Deteksi Multikolinearitas}

Uji ini merupakan suatu keadaan dimana terjadi satu atau lebih variabel independen yang berkorelasi sempurna atau mendekati sempurna dengan variabel independen lainnya. Asumsi multikolineariti ini menguji apakah dalam model regresi ditemukan adanya korelasi antar variabel independen. Model regresi yang baik seharusnya tidak terjadi korelasi diantara variabel independen. Apabila terjadi multikolineariti maka nilai estimasi parameter menjadi bias. Sehingga akan memberikan hasil verifikasi (pengujian hipotesis) yang tidak berguna bagi pengambilan keputusan (Gujarati, 2000). Untuk mengetahui ada tidaknya Multikolieritas dapat diidentifikasi dengan ciri-ciri sebagi berikut:

- Jika nilai VIF > 10 maka telah terjadi Multikolinieritas

- Jika nilai VIF <10 maka tidak terdapat Multikoliniearitas

\section{b. Deteksi Heteroskedasitas}

Uji ini bertujuan menguji apakah dalam model regresi terjadi ketidaksamaan varians dari satu residual satu pengamatan ke pengamatan yang lain. Uji di lakukan dengan cara meregresikan antara variabel indepenen dengan nilai absolut residualnya. Jika nilai signifikan antara variabel independen dengan absolut residual lebih dari 0.05 maka tidak terjadi masalah Heteroskedastisitas.

\section{c. Deteksi Autokorelasi}

Uji Autokorelasi merupakan pengujian apakah dalam model regresi linier terdapat korelasi antara 
kesalahan pengganggu pada priode $\mathrm{t}$ dengan kesalahan pada priode t1 (sebelumnya). Model regresi yang baik adalah model regresi yang bebas dari Autokorelasi. Uji Autokorelasi dilakukan dengan uji Durbin-Watson (dw) dengan ketentuan sebagai berikut:

- Jika nilai $\mathrm{p}=0$, maka tidak ada autokorelasi, maka nilai statistika dw mendekat 2

- Jika p > 1 maka, maka nilai statistika dw mendekati 0 dan ketika p mendekati -1 maka nilai statistika mendekati 4 maka terdapat autokorelasi.

\section{HASIL DAN PEMBAHASAN}

\subsection{Analisis Regresi Linier Berganda}

Perhitungan statistik dalam analisis regresi linier berganda yang digunakan dalam penelitian ini adalah dengan mengunakan bantuan program komputer SPSS for windows versi IBM SPSS Statistics 23. Hasil analisis regresi linear berganda dapat dilihat pada Tabel 1 .

Model persamaan regresi yang dapat dituliskan dari hasil tersebut dalam bentuk persamaan regresi bentuk standard adalah sebagai berikut :

$\mathrm{Y}=0,903+0,809 \mathrm{X}_{1}-0,177 \mathrm{X}_{2}+$ $0,170 \mathrm{X}_{3}-0,067 \mathrm{X}_{4}+\mathrm{e}$

Dari hasil tersebut menunjukan bahwa variabel ekonomi (X1) berpengaruh secara signifikan pada taraf $\alpha 1 \%$, faktor sosial (X2) dan kondisi lahan (X3) berpengaruh secara signifikan pada taraf $\alpha 5 \%$. Peraturan pemerintah/uu (X4) tidak berpengaruh signifikan.

Tabel 1. Hasil Analisis Regresi Linier Berganda

\begin{tabular}{|c|c|c|c|c|}
\hline No. & Variabel & $\begin{array}{l}\text { Koefisien } \\
\text { Regresi }\end{array}$ & t hitung & Sig. T \\
\hline 1 & Consant & 0,903 & 2,328 & 0,023 \\
\hline 2 & Faktor Ekonomi (X1) & 0,809 & 14,756 & (a) 0,000 \\
\hline 3 & Faktor Sosial (X2) & $-0,177$ & $-2,464$ & (b) 0,016 \\
\hline 4 & Faktor Kondisi Lahan (X3) & 0,170 & 3,195 & (b) 0,002 \\
\hline 5 & Faktor Pemerintah/UU (X4) & $-0,067$ & $-1,256$ & 0,213 \\
\hline $\begin{array}{l}\text { Sumbe } \\
\mathrm{R}^{2} \\
\text { F-hitu }\end{array}$ & $\begin{array}{l}\because \text { Data primer yang diolah, } 2016 \\
\quad=0,832 \\
\mathrm{ng} \quad=80,622\end{array}$ & $\begin{array}{l}\mathrm{N} \\
\mathrm{t}-\mathrm{T}\end{array}$ & $\begin{array}{l}\text { abel } \\
\text { bel }\end{array}$ & $\begin{array}{l}=70 \\
=2,65(\alpha=0,01) \\
=1,99(\alpha=0,05) \\
=3,62(\alpha=0,01)\end{array}$ \\
\hline
\end{tabular}

Keterangan $: a=1 \%, b=5 \%$

\subsubsection{Koefisien determinasi $\left(\mathbf{R}^{2}\right)$}

Tabel 1 menunjukkan nilai $\mathrm{R}$ Square sebesar 0,832 atau 83,2\%. Ini menunjukkan bahwa variabel keputusan petani mengkonversi lahan sawah ke lahan perkebunan yang dapat dijelaskan oleh variabel ekonomi, sosial, kondisi lahan dan peraturan pemerintah/uu adalah sebesar $83,2 \%$, sedangkan sisanya 
sebesar 0,168 atau $16,8 \%$ dijelaskan oleh faktor-faktor lain diluar penelitian ini.

\subsubsection{Uji $F$}

Hasil pengujian pada tabel 1 diperoleh nilai $\mathrm{F}$ hitung sebesar 80,622 dengan signifikan 0,000, dengan mengunakan batas signifakan 0,01. Nilai signifikan tersebut lebih kecil dari 0,01. Berdasarkan hasil perhitungan diperoleh nilai $\mathrm{F}$ hitung sebesar 80,622 dan nilai $F$ tabel sebesar 3,62. Nilai $F$ hitung > F tabel $(80,622>3,62)$ maka dengan demikian diperoleh bahwa hipotesis yang menyatakan bahwa faktor ekonomi, sosial, kondisi lahan dan peraturan pemerintah secara memiliki pengaruh yang signifikan terhadap keputusan petani mengkonversi lahan sawahnya menjadi lahan perkebunan.

\subsubsection{Uji t}

Berdasarkan hasil pengujian diperoleh bahwa masing-masing variabel yaitu faktor ekonomi (X1), faktor sosial (X2) dan faktor kondisi lahan (X3) memiliki pengaruh yang signifikan terhadap keputusan petani mengkonversi lahan sawahnya kelahan perkebunan (Y) sedangkan untuk variabel faktor peraturan pemerintah/UU tidak berpengaruh signifikan.

\subsection{Uji Asumsi Klasik}

Penelitian ini mengunakan model analisis jalur dengan mengunakan pendekatan model regresi linier berganda. Suatu model regresi yang baik harus bebas dari masalah penyimpangan terhadap asumsi klasik. Berikut ini adalah pengeujian terhadap asumsi klasik dalam model regresi.

\subsubsection{Uji multikolonieritas}

Hasil pengujian menunjukkan bahwa semua variabel yang digunakan sebagai prediktor model regresi menunjukkan VIF di bawah 10 dan tolerance di atas 0,1 . Hal ini berarti bahwa variabel-variabel bebas yang digunakan dalam penelitian tidak menunjukkan adanya gejala multikolonieritas, yang berarti variabel bebas dapat digunakan sebagai variabel indevenden sebagai pridiktor yang independen, sehingga layak untuk digunakan dalam pengujian selanjutnya. Hasil pengujian Multikoliniearitas ditunjukkan pada tabel 2 .

Tabel 2. Hasil Uji Multikolinieritas

\begin{tabular}{|l|l|l|l|}
\hline \multirow{2}{*}{ No } & Variabel & Collinearity Statistics \\
\cline { 3 - 4 } & & Tolerance & VIF \\
\hline 1 & Faktor Ekonomi (X1) &, 829 & 1,206 \\
\hline 2 & Faktor Sosial (X2) &, 990 & 1,010 \\
\hline 3 & Faktor Kondisi Lahan (X3) &, 833 & 1,201 \\
\hline 4 & Faktor Peraturan Pemerinta/UU (X4) &, 990 & 1,010 \\
\hline
\end{tabular}

Sumber : Data primer yang diolah, 2016

a.Dependen Variable : Keputusan Petani mengkonversi lahan persawahan Y 


\subsubsection{Uji Autokorelasi}

Dari hasil pengujian

Autokorelasi didapat nilai DW yang dihasilkan dari model regresi adalah 2,166 Sedangkan dari tabel DW dengan signifikan 0.05 (a 5\%) dan jumlah data $(\mathrm{n})=70 \mathrm{k}=4(\mathrm{k}$ adalah jumlah variabel independen) di peroleh nilai Dl sebesar 1,4943 dan
Du sebesar 1,7351. Nilai DW 2,166 lebih besar dari batas atas (du) yakni 1,7351 dan kurang dari (4-du) $4-1,7351=2,2649$ sehingga dapat disimpulkan bahwa tidak terdapat autokorelasi. Hasil pengujian autokorelasi ditunjukkan dengan tabel 3 .

Tabel 3. Hasil Uji Autokorelasi

\begin{tabular}{|l|l|l|l|l|l|}
\hline No & $\mathrm{R}$ & R Square & $\begin{array}{l}\text { Adjusted R } \\
\text { Square }\end{array}$ & $\begin{array}{l}\text { Std. Error of } \\
\text { the Estimate }\end{array}$ & Durbin-Watson \\
\hline 1 & $0,912^{\mathrm{a}}$ & 0,832 & 0,822 & 0,371 & 2,166 \\
\hline
\end{tabular}

Sumber : Data primer yang diolah, 2016

Keterangan : Nilai Dw $=2,166, \mathrm{DI}=1,4943, \mathrm{DU}=1,7351$

Nilai Du $(1,7352)<$ Dw $(2,166)<(4-D u) 4-17352=2,2649$

\subsubsection{Uji Heteroskedastisitas}

Berdasarkan hasil pengujian

Heteroskedastisitas di ketahui bahwa nilai signifikan variabel ekonomi (X1) sebesar 0.168, $\operatorname{sosial}(\mathrm{X} 2)$ sebesar 0,449, kondisi lahan (X3) sebesar 0,118,peraturan pemerintah (X4) sebesar 0,216lebih besar dari 0.05 ( $\alpha$ 5\%), artinya ke empat variabel independen tidak terjadi heteroskedastisitas terhadap keputusan alih fungsi lahan. Hasil pengujian heteroskedastisitas dapat dilihat pada Tabel 4.

Hasil uji heteroskedastisitas dengan metode Glesjer diperoleh nilai t-hitung lebih kecil dari t-tabel dan nilai ke empat variabel independen signifikan lebih besar 0.05 (a 5\%), sehingga dapat disimpulkan tidak terjadi masalah heteroskedastisitas sehingga model regresi layak digunakan untuk memprediksi keputusan mengkonversi lahan berdasarkan masukan atas variabel penetapan faktor ekonomi (X1), faktor sosial (X2), faktor kondisi lahan (X3) dan peraturan pemerintah/UU (X4) sehingga dapat dikatakan uji heteroskedastisitas terpenuhi.

Tabel 4. Hasil Uji Heteroskedastisitas

\begin{tabular}{|c|c|c|c|c|c|c|}
\hline \multicolumn{7}{|c|}{ Coefficients $^{\mathrm{a}}$} \\
\hline & \multirow[b]{2}{*}{ Model } & \multicolumn{2}{|c|}{ Unstandardized Coefficients } & $\begin{array}{l}\text { Standardized } \\
\text { Coefficients }\end{array}$ & \multirow[b]{2}{*}{$\mathrm{t}$} & \multirow[b]{2}{*}{ Sig. } \\
\hline & & $\mathrm{B}$ & Std. Error & Beta & & \\
\hline \multirow[t]{5}{*}{1} & (Constant) &,- 469 &, 234 & & $-2,009$ & ,049 \\
\hline & $\mathrm{X} 1$ &, 046 &, 033 & 149 & 1,393 & , 168 \\
\hline & $\mathrm{X} 2$ & ,213 & ,043 & ,482 & 4,932 & ,449 \\
\hline & $\mathrm{X} 3$ &,- 108 & ,032 &,- 359 & $-3,373$ & , 118 \\
\hline & $\mathrm{X} 4$ &, 040 &, 032 &, 122 & 1,248 & ,216 \\
\hline
\end{tabular}

a. Dependent Variable: RES2

Sumber : Data primer yang diolah, 2016 


\subsection{Pengaruh Masing-Masing Variabel Terhadap Keputusan Petani Mengkonversi Lahan Persawahan Menjadi Lahan Perkebunan}

\subsubsection{Pengaruh Faktor Ekonomi} (X1) Terhadap Keputusan Petani Mengkonversi Lahan Persawahan Menjadi Lahan Perkebunan (Y) Di

Kecamatan Sungai Batang

Nilai koefisien regresi untuk variabel ekonomi (X1) sebesar 0,809, nilai tersebut menunjukkan bahwa faktor ekonomi memiliki pengaruh yang positif terhadap keputusan petani mengkonversi lahan persawahnya menjadi lahan perkebunan di Kecamatan Sungai Batang. Fakor-faktor ekonomi yang dilihat meliputi jumlah tanggungan keluarga, pendapatan sektor pertanian yang tidak mencukupi, tuntutan hidup semakin tinggi dan modal pertanian semakin besar sehingga keputusan petani mengkonversi lahan sawahnya menjadi lahan perkebunan akan meningkat. Jika variabel-variabel ekonomi meningkat sebanyak 1(satu) satuan maka keputusan petani mengkonversi lahan sawahnya menjadi lahan perkebunan akan mengalami peningkatan sebesar 0,809 satuan dengan asumsi variabel lain konstan.

Usaha tani padi sawah membutuhkan biaya yang cukup besar, dimana kebutuhan akan sarana produksi (pupuk, pestisida) dan biaya tenaga kerja sangat tinggi. Sedangkan pada usaha tanaman perkebunan biaya yang cukup besar hanya dibutuhkan pada saat awal pelaksanaan budidaya usaha tani, selanjutnya setelah produksi biaya yang dibutuhkan cukup rendah
(Kurdianto, 2011). Hal ini adalah salah satu alasan yang menyebabkan petani mengkonversi lahan sawahnya menjadi lahan perkebunan.

\subsubsection{Pengaruh Faktor Sosial (X2) Terhadap Keputusan Petani Mengkonversi Lahan \\ Persawahan Menjadi Lahan \\ Perkebunan (Y) Di \\ Kecamatan Sungai Batang \\ Nilai koefesien regresi untuk} variabel sosial (X2) sebesar -0,177, nilai tersebut menunjukkan bahwa faktor sosial berpengaruh negatif terhadap keputusan petani mengkonversi lahan sawahnya menjadi lahan perkebunan di Kecamatan Sungai Batang. Ini menunjukkan jika faktor sosial mengalami kenaikan sebanyak 1(satu) satuan maka keputusan petani mengkonversi lahan sawahnya menjadi lahan perkebunan akan turun sebesar -0,177 satuan dengan asumsi variabel lain constant. Tradisi kegotongroyongan yang masih berjalan, nilai budaya masyarakat yang masih melekat di Kecamatan Sungai Batang dalam pengolahan lahan pertanian dan masih adanya genarasi muda yang bekerja di sektor pertanian khususnya padi sawah maka keputusan petani mengkonversi lahan sawahnya menjadi lahan perkebunan akan menurun.

\subsubsection{Pengaruh Faktor Kondisi lahan (X3) Terhadap Keputusan Petani Mengkonversi Lahan Persawahan Menjadi Lahan Perkebunan (Y) Di} Kecamatan Sungai Batang Nilai koefesien regresi untuk variabel kondisi lahan (X3) sebesar 0,170 , nilai tersebut menunjukkan 
bahwa faktor kondisi lahan memiliki pengaruh yang positif terhadap keputusan petani mengkonversi lahan persawahnya menjadi lahan perkebunan di Kecamatan Sungai Batang. Faktor-faktor kondisi lahan yang dilihat meliputi letaknya lahan yang strategis, dan luas lahan yang sempit, akan mendorong petani/ pemilik lahan untuk mengkonversikan lahannya menjadi lahan perkebunan. Jika variabel kondisi lahan meningkat sebanyak 1(satu) satuan maka keputusan petani mengkonversi lahan sawahnya menjadi lahan perkebunan akan ikut mengalami peningkatan sebesar 0,170 satuan dengan asumsi variabel lain constant.

Usaha tani tanaman padi sangat rentan terhadap kegagalan panen atau fuso hal ini dapat disebabkan oleh hama dan penyakit juga faktor alam. Pada beberapa tempat serangan yang paling berat diantaranya serangan hama tikus, serangan hama wereng dan penyakit tunggro dimana serangan tersebut kadang kala tidak bisa dikendalikan lagi sehingga bukan mendapat keuntungan malah kerugian yang diterima. Sedangkan pada tanaman perkebunan resiko kegagalan panen dan harga relatip stabil sehingga resiko yang dihadapi petani kelapa sawit tersebut sangat kecil (Kurdianto, 2011).

\subsubsection{Pengaruh Faktor Peraturan Pemerintah/UU (X4) \\ Terhadap Keputusan Petani Mengkonversi Lahan \\ Persawahan Menjadi Lahan \\ Perkebunan \\ (Y) Di \\ Kecamatan Sungai Batang}

Variabel

Peraturan

Pemerintah/UU (X4) tidak

perpengaruh signifikan terhadap keputusan petani mengkonversi lahan persawahannya menjadi lahan perkebunan. Hal ini diduga ketidaktahuan petani terhadap peraturan pemerintah/UU yang menyebabkan variabel Peraturan Pemerintah/UU tidak mempengaruhi petani mengkonversi lahan persawahannya menjadi lahan perkebunan di Kecamatan Sungai Batang.

\section{KESIMPULAN DAN SARAN}

\subsection{Kesimpulan}

1. Variabel yang berpengaruh terhadap keputusan petani mengkonversi lahan persawahannya menjadi lahan perkebunan adalah variabel ekonomi $\alpha=1 \%$, variabel sosial dan variabel kondisi lahan $\alpha=$ $5 \%$, sedangkan variabel peraturan pemerintah tidak berpengaruh signifikan.

2. Besar pengaruh setiap variabel terhadap keputusan petani mengkonversih lahan sawahnya menjadi lahan perkebunan adalah sebagai berikut :

a. Variabel ekonomi (X1) berpengaruh positif terhadap konversi lahan dengan koefisien regresi 0,809 , artinya jika variabel ekonomi meningkat sebanyak 1(satu) satuan maka keputusan petani mengkonversi lahan sawahnya menjadi lahan perkebunan akan mengalami peningkatan sebesar 0,809 satuan dengan asumsi variabel lain konstan.

b. Variabel sosial (X2) berpengaruh negatif terhadap konversi lahan dengan koefisien regresi - 0,177 , nilai tersebut menunjukkan bahwa faktor sosial berpengaruh negatif artinya kenaikan 
variabel sosial sebanyak 1(satu) satuan maka keputusan petani mengkonversi lahan sawahnya menjadi lahan perkebunan akan turun sebesar 0,177 satuan dengan asumsi variabel lain konstan.

c. Variabel kondisi lahan (X3) berpengaruh positif terhadap konversi lahan dengan koefisien regresi 0,170 , artinya jika variabel kondisi lahan meningkat sebanyak 1(satu) satuan maka keputusan petani mengkonversi lahan sawahnya menjadi lahan perkebunan akan mengalami peningkatan sebesar 0,170 satuan dengan asumsi variabel lain konstan.

d. Variabel peraturan pemerintah/uu (X4)tidak perpengaruh terhadap keputusan petani mengkonversi lahan persawahannya menjadi lahan perkebunan, di duga ketidak tahuannya petani terhadap peraturan pemerintah/uu yang menyebabkan variabel Peraturan Pemerintah/uu tidak mempengaruhi petani mengkonversi lahan persawahannya menjadi lahan perkebunan di Kecamatan Sungai Batang.

\subsection{Saran}

1. Pemerintah diharapkan memberikan penyuluhanpenyuluhan di bidang pertanian, serta memberikan pelatihan-pelatihan dan memperkenalkan inovasiinovasi terbaru mengenai pengelolaan lahan-lahan pertanian untuk dapat lebih memaksimalkan lahan- lahan pertanian yang masih tersisa yang bermanfaat bagi keberlanjutan lingkungan.

2. Sebaiknya pemerintah melakukan sosialisasi terhadap petani tentang peraturan pemerintah/uu yang menyangkut larangan alifungsi lahan tanaman pangan.

\section{DAFTAR PUSTAKA}

Arsyad, S, 1989, Konservasi Tanah dan Air, IPB Press, Bogor.

Badan Pusat Statistik. 2015. Riau Dalam Angka. BPS Provinsi Riau, Pekanbaru.

Kustiawan, I. 1997. Konversi lahan pertanian di Pantai Utara Jawa. Prisma No. 1 Tahun 1997. Pustaka LP3ES. Jakarta.

Gujarati, Damodar, 1995. Ekonometrika Dasar. Penerbit Erlangga, Jakarta. ,2000.

Ekonometrika Dasar. Penerbit Erlangga, Jakarta. 2006.

Ekonometrika Dasar. Penerbit Erlangga, Jakarta.

Irawan, Bambang dan Supeno Friyanto. 2002. Dampak Konversi Lahan Sawah di Jawa Terhadap Produksi Beras dan Kebijakan Pengendaliannya. Badan Penelitian dan Pengembangan Pertanian RI, Bogor.

Munir, Misbahul. 2008. Hubungan Antara Konversi Lahan Pertanian dengan Tingkat Kesejahteraan Rumah Tangga Petani. Skripsi. Fakultas Pertanian. Institut Pertanian Bogor, Bogor.

Nasoetion, L dan Winoto. 1996. Masalah Alih Fungsi Lahan Pertanian dan Dampaknya 
Terhadap Keberlangsungan

Swasembada Pangan.

Prosiding Lokakarya

Persaingan Dalam

Pemanfaatan Sumberdaya

Lahan dan Air: 64-82. Hasil

kerjasama PPSEP dengan

Ford Foundation, Bogor.

Pasandaran, Effendi. 2006. Alternatif

Kebijakan Pengendalian

Konversi Lahan Sawah

Beririgasi di Indonesia.

http://balittanah.litbang.depta

n.go.id diakses 16 Mei 2016.

Pakpahan, dkk. 1993. Kelembagaan

Lahan dan Konversi Tanah dan Air. PSE, Bogor.

Rahmanto, dkk, 2008. Persepsi

Mengenai Multifungsi Lahan

Sawah dan Implikasinya

Terhadap Alih Fungsi Ke

Pengguna Non Pertanian.

Pusat Analisis Sosial

Ekonomi dan Kebijakan
Pertanian Litbang Pertanian, Bogor.

Sumaryanto, et al. 1995. Analisis

Kebijaksanaan Konversi

Lahan Sawah ke Penggunaan

Non Pertanian. Laporan

Penelitian Tahun II. Pusat

Penelitian Sosial Ekonomi

Pertanian - Badan Penelitian

dan Pengembangan Pertanian, Bogor.

Sumaryanto dan Tahlim. 2005.

Pemahaman Dampak Negatif

Konversi Lahan Sawah

Sebagai Landasan Perumusan

Strategi Pengendaliannya.

Makalah yang disampaikan

pada Seminar Penanganan

Konversi Lahan dan

Pencapaian Lahan Pertanian

Abadi.

Utomo. 1992. Pembangunan dan

Alih Fungsi Lahan.

Universitas Lampung,

Bandar Lampung. 